\title{
LIFESTYLE VERSUS A PERSON'S LIFE SPAN
}

\author{
Marian Sygit, 1 , A, B, C, D Katarzyna Sygit, 1, A, B, D, E Tomasz Karkowski, , , A, D, E \\ Jan Krakowiak ${ }^{3, A, D, E}$ \\ 1 University of Szczecin, Poland, Department of Physical Education, Faculty of Physical Education and Health Promotion, Poland \\ ${ }^{2}$ University of Łódź, Poland, Department of Labor and Social Policy, Faculty of Economics and Sociology, Poland \\ ${ }^{3}$ Medical University of Łódź, Social Medicine Unit, Department of Social and Preventive Medicine, Poland \\ ${ }^{\text {A }}$ Study Design; ${ }^{\mathrm{B}}$ Data Collection; ${ }^{\mathrm{C}}$ Statistical Analysis; ${ }^{\mathrm{D}}$ Manuscript Preparation, ${ }^{\mathrm{E}}$ Funds Collection \\ Address for correspondence: \\ Katarzyna Sygit \\ University of Szczecin, Department of Health Promotion, Faculty of Physical Education and Health Promotion \\ Al. Piastów 40B, bulding 6, 71-065 Szczecin, Poland \\ E-mail: ksygit@poczta.onet.pl
}

\begin{abstract}
Ahstract Numerous studies indicate that a person's lifestyle has a positive impact on their health. However, in spite of the predominant anti-health lifestyle, the average length of life in the past few decades has increased.

What is the relation between a lifestyle and life expectancy? Does the lifestyle affect human life span?

Epidemiological and prospective-retrospective studies were used to evaluate a 20 -year long population-based experiment, which involved in-depth studies, analyses and evaluations of three related families who resided in the same community, had the same education level, and the same period of socialization and tradition. To evaluate the collected research material, the authors used their own: Scale for evaluating nutrition habits; Criteria to assess health behaviours of subjects; Criteria for diet assessment.

The studied families led a similar lifestyle, with prevalence of anti-health behaviours. Theoretically, subjects should live a similar number of years. However, the length of their lives varied. Members of families with higher number of anti-health factors lived, in fact, longer.

The authors confirmed the hypothesis that the lifestyle of the examined families was an important contributor to their health, but certainly it was not the only factor to determine their life expectancy. The length of lives of the examined family members varied despite a similar lifestyle.
\end{abstract}

Key Worlls lifestyle, health behaviours, life expectancy, old age, family

\section{Introduction}

The subject-matter literature reveals that good health (caring for one's health) determines a long life (Frąckiewicz, 1989, 1999; Ostrowska, 1999; WHO, 2011; Sygit, Sygit, 2008; Sygit, 2010).

Health is influenced by many factors, presented in the so-called Lalond model. These are: lifestyle (about $52 \%$ ), physical environment (20\%), genetic conditioning (20\%), and health care (8\%) (Sygit, 2010; Kulik, Pacian, 2014). 
Healthy lifestyle has the biggest positive effect on health, i.e. rational nutrition, physical activity, rest, stress avoidance, refraining from smoking tobacco and drinking alcohol (Ostrowska, 1999; Sygit, 2010; Bouchard, Blair, 2007; Flatcher, Balach, Blair, 1996; Karski, 2003; Kosińska, 2006). The most important factors from the abovementioned are: physical activity and rational nutrition (including reduced consumption of high-fat products (pork) in favour of white meat (fish, poultry) (Sygit, 2010; Kosińska, 2006; Booth 2000; Craig et al., 2003; Ekelund et al., 2007; Gawędzki, Hryniewiecki, 1988; Gill, 1997; Horst, Paw, Twisk, Van, 2007).

Health education promotes, or even appeals for, physical activity and preventive medical check-ups (Frąckiewicz, 1999; Booth, 2000; Craig et al., 2003; Jarosz, 2006; Nawojek, 1993; Drabik, Resiak, 2010; Gorret, 1990).

The importance of a healthy lifestyle has become the subject of a number of studies and analyses which encompass populations of all ages (Jabłoński, 1998). Many studies have shown that the level of physical activity, which is the foundation of human health, was very low (Janssen, 2007; Kalman et al, 2015; Karasek, 2003; Siciński, 2002; Snitor, Krak, 2007). It has also been found that nutrition habits were irrational and there were many anti-health factors (such as smoking, drinking alcohol, chemical stimulants) and environmental factors present. Nevertheless, it is observed that the average life expectancy of a person is increasingly longer. Over the past decades, there has been a significant increase in life expectancy in Poland. Currently, the average life span of a woman is 81.6 years, while for a man it is about 73.8 years. In other countries, such as Japan, the average is 91 years (Ostrowska, 1999; Wrzesiński, 1993; Frączak, 1984; Pędich, 1995).

Some literature findings indicate that - in spite of the continued prevalence of anti-health factors - the population has lived longer and longer over the past several decades (Frąckiewicz, 1999; Janssen, 1998; Kalman et al., 2015).

Human longevity research brings new insights and brings us closer to answering the question: What to do and how to live to be 100 years and more?

The aging process is still undiscovered. There are many theories of aging. We do not know, however, what determines the length of a person's life (Frąckiewicz, 1999; Sygit, 2010; Sygit, 2009).

The purpose of this paper is to find an answer to the following question: How does lifestyle affect the lifespan of a person?

Monitoring a person's lifestyle over a long period of time (especially in a form of family studies) can bring us closer to identifying a recipe for longevity.

The following hypotheses were made:

- it is assumed that lifestyle is the main determinant of a person's lifespan, as it significantly affects their health,

- it is assumed that people who have similar lifestyles, residing in the same environment, related to one another, doing the same type of work and having similar education level, would display similar health and reach similar life expectancy.

\section{Materials and methods}

Prospective-retrospective study was used to assess a 20 -year long population-based experiment, involving three related families which resided in the same community (a village in Kujawy, Poland) (Table 1). 
Table 1. Summary of families

\begin{tabular}{|c|c|c|c|c|c|}
\hline \multirow{2}{*}{ Family } & \multirow{2}{*}{ Wife } & \multirow{2}{*}{ Husband } & \multirow{2}{*}{$\begin{array}{c}\text { (Number of) } \\
\text { children }\end{array}$} & \multicolumn{2}{|c|}{ Grandchildren } \\
\hline & & & & men & women \\
\hline 1 & A & $\mathrm{A} 1$ & 6 & 3 & 5 \\
\hline 2 & B & B1 & 1 & 3 & 1 \\
\hline 3 & C & $\mathrm{C} 1$ & 1 & - & 1 \\
\hline Total & 3 & 3 & 8 & 6 & 7 \\
\hline
\end{tabular}

The analysis focused in particular on:

- data collected from the family members on their daily lives,

- information from various documents held by the families,

- information collected from living members of the families (children and grandchildren),

- interviews and opinions of friends, neighbours, including own autopsy,

- results of studies, analyses and observations collected in the course of study.

Criteria for assessing health behaviours (Table 2) were developed to assess health behaviours of the subjects (including their predominantly anti-health behaviours).

Table 2. Criteria used to assess health behaviours of subjects

\begin{tabular}{cl}
\hline Number & \multicolumn{1}{c}{ Applied criteria } \\
\hline 1. & Smoking (at least $10 \mathrm{pcs}$. daily) \\
2. & Drinking alcohol (at least $100 \mathrm{~g}$ daily) \\
3. & Consumption of red meat (pork, beef) at least 3 times per week \\
4. & Physical activity (working in the field, on the farm - daily) \\
5. & Consumption of vegetables, fruit, salads (at least 3 times per week) \\
6. & Performing preventive medical check-ups (at least every second year) \\
7. & Excessive salting of food (frequent) \\
\hline
\end{tabular}

A scale for assessment of dietary habits was developed to evaluate nutrition routine of the subjects (Table 3).

Table 3. Scale for evaluating nutrition habits

\begin{tabular}{cll}
\hline \multirow{2}{*}{ Number } & \multicolumn{1}{c}{ Independent variables } & \multicolumn{2}{c}{ Number of families that were rated } \\
\cline { 3 - 3 } & & \\
\hline 1. & Daily consumption of & \\
2. & Breakfast $(\mathrm{A})$ & \\
3. & Elevenses \\
4. & Lunch & \\
5. & High tea \\
6. & Dinner & \\
7. & Snacking between meals & \\
\hline
\end{tabular}


To assess subjects' weekly diet, criteria for evaluating the diet (Table 4) were developed.

Table 4. Criteria for diet assessment

\begin{tabular}{lccc}
\hline \multirow{2}{*}{ Criteria } & \multicolumn{3}{c}{ Of the assessment } \\
\cline { 2 - 4 } & very good & good & sufficient \\
\hline Carbohydrates & 3 times per day & 3 times per day & 3 times per day \\
Protein & 3 times per day & 2 times per day & Once per day \\
Fats & 2 times per day & Once per day & 3 times per day \\
Vitamins and minerals (fruit and vegetables) & $1-3$ times per day & $0-2$ times per day & $0-1$ per day \\
\hline
\end{tabular}

In total, 100 menus per year were assessed during the study period. The collected data, observations, interviews and autopsy data provided an unbiased overview of the weekly dietary habits, lifestyle characteristics and description of family history of all three families.

\section{Resulls. Commentary}

\section{The overview of the subjects}

The study which is being described in this paper, included three related families living in their homes (farms) in the countryside, as neighbours. The families were a rare case, and thus they became particularly interesting due to their life histories and objective assessment.

These families included:

1. Three sisters $(\mathrm{W})$ who got married with three brothers $(\mathrm{S})$ :

- family of the sisters: 4 sisters and 1 brother,

- family of the brothers: 4 brothers and 1 sister.

2. Observations and analyses focused on the three women (sisters) from the $W$ family who married three men (brothers) from the $S$ family.

Parents of the women (sisters) died at the age of 60 (father) and 52 (mother). Parents of the men (brothers) died at the age of 65 (father) and 63 (mother). Parents of brothers (men) were healthy, while the mother of sisters (women) was ill (probably with diabetes).

1.2. Body mass of women and men:

- all women (sisters) were obese (BMI > 30),

- the men (brothers) had correct body weight, they were thin, without a trace of overweigh $(\mathrm{BMI}<24)$.

1.3. Diseases in the surveyed families:

- Family 1 had hypertension (A1), (A) and diabetes (A),

- Family 2 had (a probable) prostate cancer at the end of life (B1). By contrast, (B) was never ill. At the end of life, she fell and fractured her hip. She had never been to a doctor before that,

- Family 3 (C) suffered from diabetes, followed by total blindness, (C1) was not ill.

1.4. Diseases of children in the surveyed families:

- Family 1 - son and daughter suffering from diabetes,

- Family 2 - the only son had hypertension, while his three sons are diabetic,

- Family 3 - daughter (a single child) suffered from diabetes, while her children are healthy (Table 5). 
Tahle 5 . Diabetes among children in the surveyed families

\begin{tabular}{cccc}
\hline Family & Women & Men & Total number of children \\
\hline 1 & - & 1 & 6 \\
2 & - & - & 1 \\
3 & 1 & - & 1 \\
\hline Total & 1 & 1 & 8 \\
\hline
\end{tabular}

\section{Lifestyle of the families}

2.1. Health behaviours of the subjects. The health behaviours of the family members were assessed with certain criteria (Table 4) to identify the prevalence of anti-health behaviours. The assessment showed a high incidence of these behaviours (i.e. disease risk factors), especially those related to red meat consumption, adding salt to dishes and skipping preventive medical check-ups. The number of anti-health behaviours was higher among men (husbands) than women (wives). The assessed pro-health factor was physical activity (daily hard work in the field and on the farm, which provided a lot of physical stimulation) (Table 6).

Tahle 6 . Anti-health behaviours of the families

\begin{tabular}{|c|c|c|c|}
\hline \multirow{2}{*}{ Number } & \multirow{2}{*}{ Independent variables } & \multicolumn{2}{|c|}{ Family members } \\
\hline & & women & men \\
\hline 1. & Smoking tobacco & - & 1 \\
\hline 2. & Drinking alcohol & 1 & 1 \\
\hline 3. & Consumption of red meat (pork, beef) & 3 & 3 \\
\hline 4. & Low physical activity & 1 & - \\
\hline 5. & Consuming fruit, vegetables and salads less than 3 times per day & 2 & 1 \\
\hline 6. & Skipping preventive medical check-ups & 1 & 3 \\
\hline 7. & Adding salt to dished (excessive salting) & 2 & 3 \\
\hline \multicolumn{2}{|c|}{ Positive assessment } & - & - \\
\hline \multicolumn{2}{|c|}{ Negative assessment } & + negative & + negative \\
\hline \multicolumn{4}{|c|}{$\begin{array}{l}-4 \text { negative factors - negative score, } \\
-3 \text { negative factors - sufficient score, } \\
-2 \text { negative factors - good score. }\end{array}$} \\
\hline
\end{tabular}

Only one man smoked tobacco (and drank alcohol), while only one woman drank alcohol - $100 \mathrm{~g}$ of pure spirit daily at dinner.

Nutrition habits of the subjects.

A scale for assessment of dietary habits was developed to evaluate nutrition routine of the subjects (Table 6).

Families consumed 3 meals daily: breakfast, lunch and dinner. They did not have elevenses or high teas. The times of meals were not the same (meal times and times between meals varied), as meals depended on their work. The number of negative scores exceeded the number of positive ones (Table 7). 
Table 7. The assessment of nutrition habits of the subjects, according to the assessment scale

\begin{tabular}{|c|c|c|c|c|}
\hline \multirow{2}{*}{ Number } & \multirow{2}{*}{ Independent variables } & \multicolumn{2}{|c|}{ Number of families that were rated } & \multirow{2}{*}{ The number of positive and negative scores } \\
\hline & & positively (A) & negatively (B) & \\
\hline \multicolumn{5}{|c|}{ Daily consumption of } \\
\hline 1. & Breakfast & 3 & 0 & $p>n$ \\
\hline 2. & Elevenses & 0 & 3 & $p<n$ \\
\hline 3. & Lunch & 3 & 0 & $p>n$ \\
\hline 4. & High tea & 0 & 3 & $p<n$ \\
\hline 5. & Dinner & 3 & 0 & $p<n$ \\
\hline 6. & Snacking between meals & 1 & 1 & $p=n$ \\
\hline 7. & Frequency of meals & 1 & 2 & $\mathrm{p}<\mathrm{n}$ \\
\hline
\end{tabular}

Favourite (preferred) meals were: lunch, breakfast and dinner. Dominant food product and dishes were: bacon, pork, potatoes, bread, pancakes. Unpopular products were: salads, fruit, fish and cakes. The distribution of favourite foods and meals was very similar among the families (Table 8).

Table 8. Preferred foods, meals, dishes

\begin{tabular}{lccc}
\hline \multirow{2}{*}{ Preferred (favourite) } & \multicolumn{3}{c}{ Families } \\
\cline { 2 - 4 } Breakfast & A & B & C \\
Lunch & +++ & +++ & +++ \\
Dinner & +++ & +++ & +++ \\
\hline & ++ & ++ & +++ \\
\hline Bacon & Products & & ++ \\
Lard & ++ & +++ & +++ \\
Pork & +++ & ++ & +++ \\
Poultry & +++ & +++ & ++ \\
Milk & ++ & ++ & ++ \\
Potatoes & ++ & ++ & +++ \\
Bread & +++ & +++ & +++ \\
Groats & +++ & +++ & ++ \\
Salads & ++ & + & + \\
Fruit and vegetables & + & + & + \\
Fish & + & + & + \\
\hline & & & ++ \\
\hline Pierogi dumplings & Dishes & & + \\
Pancakes & ++ & ++ & + \\
Cakes & +++ & + & + \\
\hline
\end{tabular}

Criteria for assessment:

- very high degree of preference $=+++$,

- moderate degree of preference $=++$,

- low degree of preference $=+$

The sum of ratings: there were 20 very good scores, 13 good scores as 11 low scores. 
The criteria used to evaluate selected weekly menus from every 100 menus evaluated each year showed that most of them received 'very good' scores, some received 'good' scores, while few received 'sufficient' scores. (Table 9).

Table 9. Summary of average scores for selected weekly menus of the families

\begin{tabular}{ccccc}
\hline \multirow{2}{*}{ Family } & \multicolumn{2}{c}{ Number of menus which were rated: average values } & \multirow{2}{*}{ Number of rated days per week } \\
\cline { 2 - 4 } & very good & good & sufficient & 7 \\
\hline 1 & 3 & 2 & 2 & 7 \\
2 & 4 & 2 & 1 & 7 \\
3 & 4 & 2 & 1 & 7 \\
\hline
\end{tabular}

On average, the subjects consumed carbohydrates (mainly bread) 3 times per day; proteins (dairy products, smoked meat) were not always consumed 3 times per day; while fats were consumed 3 times per day (mainly in the form of bacon and lard), but not all menus included them 3 times per day. Salads and fruit were eaten rarely (salads were limited mainly to sauerkraut and cucumbers).

\section{Length of life}

The length of a person's life is undoubtedly dependent on many factors, amongst which the state of health (i.e. not only the lack of disease but a set of psychophysical factors) plays an important role. In turn, the state of health depends - according to Lalond - in up to $50 \%$ on the individual's lifestyle. A positive lifestyle is, to some extent, a guarantee of a long life. The life expectancy of men in Poland in 2015 increased by 0.7 year to 73.8 , and of women by 0.5 , to 81.6 .

The lifestyle of the subjects (members of the families) was similar. They experienced diseases, especially women. These diseases were: diabetes in women (A) and (C), as well as hypertension in men (A1) and women (A).

All women were obese.

The longest-living woman (B): 86 years old, never sick, obese, not physically active, drank alcohol (every day). Her sisters lived much shorter lives. She was the only one without diabetes. Among men, (A1) had the longest life: he was thin (like other brothers), but unlike them, he drank alcohol (several times a week) and smoked a lot (about 15-20 cigarettes a day) (Table 10).

Table 10 Subjects' length of life

\begin{tabular}{cccc}
\hline \multirow{2}{*}{ Family } & \multicolumn{2}{c}{ Length of life (years) } & \multirow{2}{*}{ Total years of life of family members } \\
\cline { 2 - 3 } & wife & husband & 154 \\
2 & A 82 & A1 72 & 150 \\
3 & B 86 & B1 64 & 132 \\
\hline Total years of life & C 72 & C1 66 & 442 \\
\hline
\end{tabular}

The length of life varied despite similar lifestyles of both men and women in the families. A comparison of length of life of the family members showed that: Family 1 had the highest total of years lived; the amount was 
insignificantly higher than in Family 2, and significantly higher than in Family 3. The sum of years of life of women (sisters) in the families was 38 years higher than the sum of years of men's life. These results confirm a large variation in the length of lives among families and among women (wives, sisters) and men (brothers, husbands), despite similar standards of living, living environment and similar life conditions (standard of life).

\section{Discussion}

The results of longitudinal studies on lifestyle, health and length of life have not been presented in the literature so far.

Long-term studies and observations of families, including their members living in the same environment, related to each other, leading a similar lifestyle and having similar work (agriculture), bringing up children, may be an important contributor to the knowledge on epidemiology of the prevalence and spread of particularly chronic diseases in terms of the influence of external, environmental, and personal factors on one's health and life expectancy. Research on families who live in similar conditions may help answer questions about a person's life style versus their life span (Bouchard, Blair, 2007; Flatcher, 1996; Ekelund et al., 2007).

The presented results of a 20 -year long study on Polish families living in a rural environment with similar lifestyles, related to each other, provided interesting observations. Many results point to the anti-health lifestyle of the population, on the basis of which the future health of the population is forecast. At the same time, we experience a civilization progress, improvement of living standards, increase of the average life expectancy and developments related to certain health conditions (Halicka, Pędich, 1997; Pędich, 1965; Piotrowski, 1973; Karski, Pawlak, 2003; Miker, Gębska-Kuczarowska, 1988). So, what is the role and importance of a lifestyle?

The 20-year long observation leads us to believe that: in families with a similar lifestyle (similar nutrition, physical activity, leisure) theoretically the wives (sisters) and their husbands (brothers) should live a similar number of years. However, there were significant differences, which may indicate other factors responsible for life expectancy. In the studied families, men from families without chronic diseases (including diabetes) were not ill, and enjoyed good health (one of the men had mild hypertension).

Analogically, women from a family with chronic diseases (diabetes) had diabetes as well. One of them was not ill. They were obese throughout their adult (married) life.

How were the subjects different?

As for the women (sisters), they all came from a family with diabetes, had a similar lifestyle, and were not hospitalized. One of them was not diabetic, but was the least active physically; she never had any health issue and did not require treatments. She drank a glass (about $100 \mathrm{~g}$ ) of pure spirit every day. Her only son was not diabetic, but his three sons are all diabetic. She lived the longest among the sisters and among all subjects in the family.

As for men: they all had healthy parents, led a similar lifestyle, and were very physically active. They were healthy and did not suffer from diabetes. One of them drank alcohol (several times a week) and smoked cigarettes. He had hypertension. He lived the longest of all the brothers.

Theoretically, the sisters (wives) and brothers (husbands) should live a similar number of years. The differences in the length of their lives were related to their health. Members of families with higher number of risk factors (alcohol, tobacco) lived, in fact, the longest. All the subjects lead a similar lifestyle (in most cases, it was not healthy) and yet women who were obese and (two of them) had diabetes lived longer than men (their husbands) who also had similarly unhealthy habits, but lived much shorter, even though they did not suffer from obesity or diabetes. 
Studies on longevity indicate cases of smoking (but often the tobacco came from subjects' own farm: Nicotina tabacum) and alcohol consumption of the long-living individuals (Ostrowska, 1999; Manton, 1998; Klonowicz, 1979; Synck, 2002). The lack of similar observations (and family studies) in the long perspective makes it impossible to compare the cases, but sheds some light on the role of lifestyle and its importance for human life. Researchers are aware that the observations, despite a 20 -year period and only three families involved (although their situation was dictated by life, and therefore used in the experiment) do not allow for generalizations, but are a significant contributor to further research.

\section{Conclusions}

Based on the results obtained from 20-year long observations and studies on lifestyles and life expectancy, it was found that:

1. The authors confirmed the hypothesis that the lifestyle of the examined families was an important factor of their health, but certainly it was not the only one (and possibly not the key factor) to determine their life expectancy.

2. Life expectancy of the family members was varied despite their similar lifestyles.

3. Anti-health behaviours were dominant in the lifestyle of the subjects.

\section{References}

Booth, M.L. (2000). Assesment of Physical Activity: An International Perspective. Res. Quart. Exerc. Sport, 71 (4),114-120.

Bouchard, C.L., Blair, S.N. (2007). Why Study Physical Activity and Health? In: C. Boucherd, S.N. Blair, W. Haskell (eds.) Physical Activity and Health, Champaign, IL. Human Kinetics 16 (2); 67-73.

Craig, C.L., Marshall, A.L., Sjostrom, M., Baumann, A.E., Booth, M.L., Ainsworth, B.E., Pratt, M., Ekelund, V., Yngve, A., Sallis, J.F., Oja, P. (2003). International Physical Activity Questionnaire: 12-country relibility and validy. Medicine \& Science In Sport \& Excercise, 35 (1), 1381-1395.

Drabik, J., Resiak, M. (2010). Styl życia w promocji zdrowia. Gdańsk: AWF.

Ekelund, V., Anderssen, S.A., Froberg, K., Sardinka, L.B., Andersen, L.B., Brage, S. (2007). Independent associations of physical activity and cardioresipiratory fitness with metabolic risk factors in children: the Eurorean younth heart study. Diabetologia, 50 (2), 1832-1840

Flatcher, G.F., Balach, G, Blair, S.N.(1996). Statement on exercise; Benefits and recommendation for physical activity programs for All Americans - A statement for health Professional by the committee on exercise and cardiac rehabilitation of the council on clinical cardiology. American Heart Association. Cir, 94 (4), 857-862.

Frąckiewicz, L. (1999). The aging of the population of Poland and its consequences. Katowice: Publ. Legal, Economic and Social Movement.

Frąckiewicz, L. (ed.) (1989). Factors affecting the health of the population. Katowice: Publ. SIN.

Frączak, J. (1984). Proces starzenia się ludności Polski a proces urbanizacji. Monografie i Opracowania nr 149, Warszawa: SGPiS.

Gawędzki, J., Hryniewiecki, L. (1988). Żywienie człowieka. Podstawy nauki o żywieniu. Warszawa: PZWL.

Gill, G. (1997). Potrzeby zdrowotne osób starszych. Warszawa: PZWL.

Gorret, G. (1990). Potrzeby zdrowotne ludzi starszych. Warszawa: PZWL.

Halicka, M,. Pędich, W. (1997). Działalność samopomocowa ludzi starszych. Białystok: Publ. AM.

Horst, V.D., Paw, M.J., Twisk, J.W., Van, M. (2007). A Brief Review on Correlates of Physical Activity and Sedentariness. Med Sci Sports Exerc.,39 (8),1241-1250.

Jarosz, M. (ed.) (2006). Otyłość, żywienie, aktywność fizyczna Polaków. Warszawa: Wyd. Inst. Żyw. i Żyw.

Jabłoński, L. (ed). (1998). Sanologia, nauka o zdrowiu społeczeństwa. Warszawa: Wydawnictwo WSRL. 
Janssen, J. (2007). Physical activity, fitness and cardine, vascular and pulmonary morbidities. Human Kinetics, Champaign,16 (2), 161-172.

Kalman, M., Inchley, J., Sigmundova, D., lannotti, R.J., Hamrik, Z., Hang, E., Bucksch, J. (2005). Secular trends In moderate-tovigorous physical activity in 32 countries from 2002 to 2010: a cross-national perspective. European Journal of Public Health, 25 (3), 37-40.

Karasek, M. (2003). Starzenie się populacji światowej i jego konsekwencje. Folia Medica, 30 (1), 89-94.

Karski, J. (ed.) (2003). Promocja zdrowia. Warszawa: CeDeWu.

Karski, J., Pawlak, J. (2003). Środowisko i zdrowie. Warszawa: CeDeWu.

Klonowicz, S. (1979). Oblicza starości. Warszawa: WP.

Kosińska, M. (ed.) (2006). Styl życia dla zdrowia. Żywiec: Beskidzka Wyższa Szkoła Umiejętności.

Kulik, T.B., Pacian, A. (2014). Zdrowie publiczne. Warszawa: PWN.

Manton, K.G. (1998). Longitudinal study of functional change and mortality In the United States. Journal of Gerontolog, 41 (2), 45-51.

Miker, M., Gębska-Kuczarowska, A. (1988). Ocena stanu zdrowia ludzi w starym wieku w Polsce. Gerontologia Pol., 3-4,77-82.

Nawojek, L. (1993). Niektóre aspekty uwarunkowań zachowań żywieniowych. Warszawa: Wyd. Inst. Żyw. i Żywn.

Ostrowska, A. (1999). Styl życia a zdrowie. Z zagadnień promocji zdrowia. Warszawa: Inst. Filozofii i Socjo. PAN.

Pędich, W. (1995). Pacjent w starszym wieku. Warszawa: PWN.

Pędich, W. (1965). Badania nad stanem zdrowia i warunkami życiowymi ludzi starszych w Opolu. Warszawa: PWN.

Piotrowski, J. (1973). Miejsce człowieka starego w rodzinie i społeczeństwie. Warszawa: PWN.

Siciński, A. (2002). Styl życia. Warszawa: Inst. Filozofii i Socjologii. PAN.

Snitor, C.W, Krak, V.I. (2007). Adeqnacy of evidence for Physical Activity Guidelines Dvelopment: Workshop Summary. Washington: The National Academies Press.

Sygit, K. (ed.) (2009). Zarys gerontologii. Szczecin: Wydawnictwo Naukowe Uniwersytetu Szczecińskiego.

Sygit, M. (2010). Zdrowie publiczne. Warszawa: Wolter Kluwer.

Sygit, M., Sygit, K. (2008). Wychowanie zdrowotne. Szczecin: Wydawnictwo Naukowe Uniwersytetu Szczecińskiego.

Synck, B (ed.) (2002). Polska starość. Gdańsk: Uniwersytet Gdański.

WHO (2011). Word Health Organization. Report. Global status report on noncommunicable diseases 2010.

Wrzesiński, K. (1993). Styl życia a zdrowie. Wzór zachowania. Warszawa: Publ. Inst. Psychologii PAN.-

Cite this article aS: Sygit, M., Sygit, K., Karkowski, T., Krakowiak, J. (2018). Lifestyle versus a Person's Life Span. Central European Journal of Sport Sciences and Medicine, 2 (22), 51-60. DOI: 10.18276/cej.2018.2-06. 